\title{
TWO-DIMENSIONAL HYDRODYNAMIC MODELLING OF URBAN FLOOD INUNDATION CAUSED BY THE SOUTHWEST MONSOON TO CHARACTERIZE THE IMPACT OF TWENTY-YEAR DIFFERENCE IN LAND USE IN VALENZUELA-OBANDO-MEYCAUAYAN (VOM) USING FLO-2D
}

\author{
Adrian Christopher E. Cruz ${ }^{1}$, Jason Matthew D. Dizon ${ }^{1}$, Ricca Bienna Larizza M. Mediavillo ${ }^{1}$, Bianca O. Nepomuceno ${ }^{1}$, Armi \\ Cunanan-Yabut ${ }^{1}$, John Manuel B. Vergel ${ }^{1}$
}

${ }^{1}$ Department of Civil Engineering, FEU Institute of Technology - adriancruz20.ac@gmail.com

Commission IV

KEY WORDS: Urban Hydrology, Land Use Change, Hydrodynamic Modelling, Southwest Monsoon, FLO-2D

\begin{abstract}
:
The intensity of urban flooding area due to rapid urbanization in Metro Manila has been worsening over the years caused by the torrential rains brought by the Southwest Monsoon. To further characterize the impact of land use change influenced by urbanization, we compared the flood map generated from two periods (Year 200 \& Year 2020) using a two-dimensional hydrodynamic modelling simulated in FLO-2D software. In our simulations, we assigned roughness coefficient values to corresponding land use category derived from an earlier study in the area previously spearhead by JICA in 2001. Each model will incorporate the implemented Year 2000 land use and the projected Year 2010 land use classification respectively, which were used in this earlier study. Meanwhile, both models will use the same sets of parameters for the simulation: IFSAR-derived DEM elevation model and a rainfall event with 10-yr return period. The area of interest of this study is located near Valenzuela-Obando-Meycauayan (VOM) with its boundaries defined from the National Mapping and Resource Information Authority. The flood simulations conducted do not take into consideration in existing flood control measures such as drainage systems and floodwalls to minimize the complexity of the model. The results are evaluated both quantitatively and qualitatively. According to the results, the impact of the land use change on flood formation in most areas are insignificant due to a low degree of land use change. However, there has been substantial impact on flooding in specific areas where there is a major change in the land use. For further studies, we recommend the use of a longer land use change period and the consideration of more varied and precise Manning's n-values.
\end{abstract}

\section{INTRODUCTION}

\subsection{Flooding and Flood Modelling}

The United States Geological Survey describes flood "as relatively high water that overflows the natural or artificial banks of a stream or coastal area that submerges land not normally below water" (USGS.com, 2007). Flooding is a naturally occurring event that happens when water overflows due to exceeding the volume capacity of a system. The Economic and Social Commission for Asia and the Pacific (ESCAP/UN), an organization under the jurisdiction of the United Nations have cited some of the effects of flood that directly affect human activity; loss of life, property damages, interruption of transportation networks, communications systems, suspension of health and community service, damages in the agriculture sector, and business profit losses. However, some indirect effects of flooding are deemed to be extremely devastating. The adverse influence to countries' economies due to flooding is most likely worse for developing countries whose economic growth rely on such infrastructures (Manual and Guidelines for Comprehensive Flood Loss Prevention and Management, 1991).

Flooding is also influenced by land cover, also known as land use. As per Manning's Formula, the velocity of water is depended also in surface roughness (Chow, 1988). And this specific parameter is tied with urbanization. The rapid urbanization over the years would results to former agricultural lands transformed into roads and urban areas. These changes in land use would make the soil non-permeable. With the surface, impermeable for water, instead of infiltrating downwards to recharge the ground water table, the water will instead undergo runoff process and be collected in a much lower elevation (Maidment, 1993). Unfortunately, if the catchment area where the water is stored cannot be drained out or non-permeable, water will just stay on one place and create depression storages.

The disturbing aftermath of flooding has raised the attention for the growing necessity to mitigate flooding-induced damages in our communities. According to a 1991 report of the ESCAP/UN, controlling damages caused by flooding is possible using two methods; approaching the mitigation using structural and nonstructural technique (Manual and Guidelines for Comprehensive Flood Loss Prevention and Management, 1991). These structural approaches can consist of constructing reservoirs, dams and dikes and enhancements of channel intended in minimizing the degree of flooding. Mitigating floods by controlling it using hydraulic structures are also approaches planned to divert flood water away from the urban areas and population centers. Despite of this approach in mitigation being proven effective, it is also often expensive.

On the other hand, the non-structurally technique in controlling flood-induced damages relocates the population away from the affected area of flooding. This approach is proposed in order minimize the effects of flood inundations towards community and to the country's economy in long term. This include; formulations of protocols in the forecasting of flooding and earlywarning systems, urban zoning and land use planning and flood insurance. Hydraulic and hydrologic models are most commonly used in forecasting floods and the establishment of flood earlywarning protocols (Flood Forecasting and Early Warning, 2013). Optimally calibrating and validating these can be used as an instrument towards controlling damages caused by flooding 
under non-structural approach (Manual and Guidelines for Comprehensive Flood Loss Prevention and Management, 1991).

The simulation of flooding having its roots during its early days using a simple lumped model has transformed with very intricate advancements in the remote sensing field and the utilization of geographic information technologies (GIS) (Smith, 1997). Currently, flood modelling analysis is divided into two distinct methods, namely one-dimensional and two-dimensional (Rientjes, 2007). One-dimensional flood modelling is used on simulating stream and open channel flow while two-dimensional flood modelling is concerned on overland flow and run-off simulation (Ruji, 2007). Using flood models, researchers would be able to identify where in the vicinity are flood-prone areas and to investigate the behavior of the movement of water across the given area, under specific rainfall parameters and based on the values of the Manning's coefficient of the land cover from the digital surface model and the values of Green-Ampt model parameters for ground infiltration (Green \& Ampt, 1911). These models generated by software like Flo-2D are analyzed in drafting and formulating zoning districts in urban planning. Knowing where and how the flooding will occur is crucial in layouting future land use plans to keep away primary industries and crucial urban areas from flooded areas (Haan, Johnson, \& Brakensiek, Hydrologic Modelling of Small Watersheds, 1982). Government agencies such as Project Noah and PAGASA would then interpret the hydraulic/hydrologic simulation model into flood hazard maps depending on their return period using GIS software like ArcGIS.

\subsection{Southwest Monsoon}

Monsoons trigger the onset and recession of the rainy season in the Philippines. The Southwest monsoon may begin as early as mid-April and end as late as early November depending on location. When the southwest monsoon and tropical cyclone seasons are dominant, the western coastal areas receive heavy rainfall that may trigger flooding and landslides (Manual on Flood Control Planning, 2003). With the current state of climate change, typhoons don't even have to pass through Metro Manila in order for flooding to occur in the area. Torrential rains which are categorized as higher than 30 millimeters of rainfall in an hour and are often associated with the Southwest Monsoon have been the common rainfall event where flooding occurs in the Metro Manila area. Since 2012, there's a specific span of days in August to September when class and work suspension would be declared in the Metro due to non-stop heavy rainfall and the flooding that came along with it. And in this span of time Metro Manila is paralyzed, losing a substantial amount of money due to the disruption of economic activity and to considerable longlasting property damages. There are some areas even after the raining had ceased, still were heavily flooded. These areas, as defined by hydrologists as depression storages are where the flooding is accumulated and is not able to drain by natural means. These depression storages are commonly found in low-lying areas near the coastlines such as Kalookan-Malabon-NavotasValenzuela (KaMaNaVa) and Valenzuela-ObandoMeycauayan(VOM). Identifying these depressions will help in layouting drainage outlets efficiently.

\subsection{Valenzuela-Obando-Meycauayan as the Study Area}

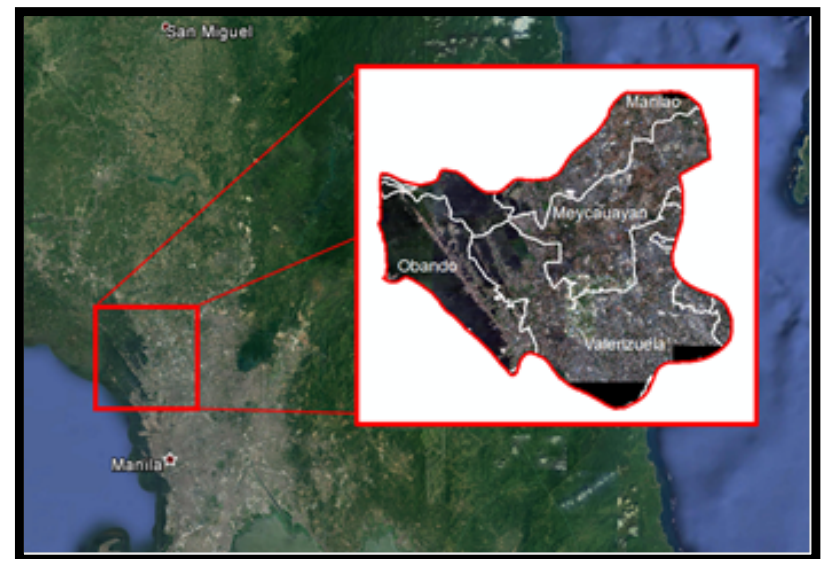

Figure 1. Valenzuela-Obando-Meycauayan Area (VOM)

The study area, Valenzuela-Obando-Meycauayan (VOM), is located in the northwest of Metropolitan Manila. Flooding has been a huge problem for urban development in the ValenzuelaObando-Meycauayan (VOM) area for the past years. Numerous studies both foreign and local spearheaded were conducted in the area in the past to propose a viable solution to effectively mitigate and control the flooding. One of them was a joint effort by the Japan International Cooperation Agency (JICA) and the local government that conducted a previous feasibility study for an implementation of a drainage system in the area using a quasilinear run-off model from which the land use parameters used in this study were derived from (CTI Engineering, 2001). The flooding phenomenon according to these studies is attributed to several factors like flood surges from the inundation of the Meycauayan river and its tributaries, the downstream elevation of $\mathrm{KaMaNaVa}$ and the elevation of the area with respect to the sea level. Existing flood control measures has been designed to accommodate the flooding on the levels of Typhoon Ondoy, however, these measures are only limited to its location's vicinity and rainfall duration with parameters like Ondoy (Badilla, 2008). This study will cover a flood simulation of the area by linked 1D/2D modeling using historical Southwest Monsoonal rainfall intensity and from this hydrologic/hydraulic model, will generate a flood hazard map of the area over specific periods.

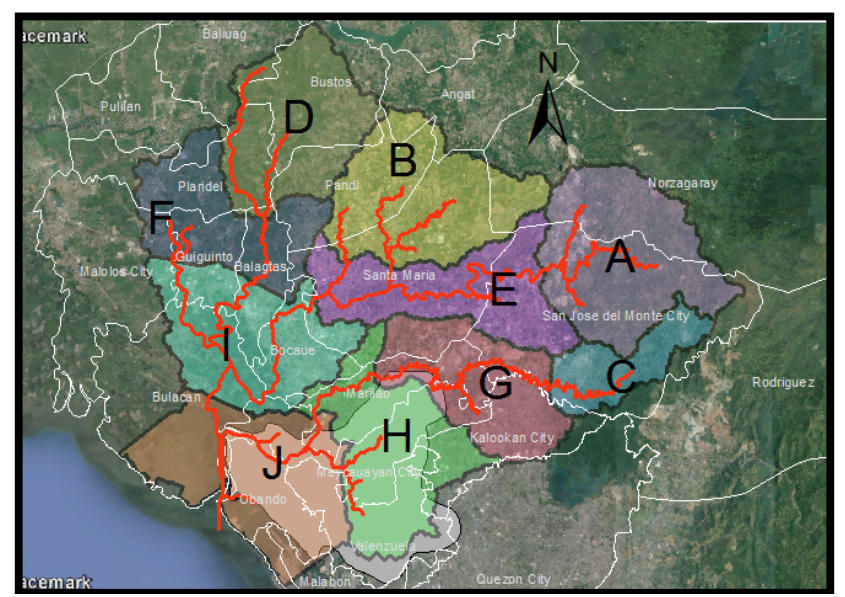

Figure 2. Meycauayan River Basin

Land use is heavily influenced by the level of human development in the area (Santillan, Paringit, \& Makinano, 2011). This extent of urbanization can be measured through the area of its scope and the density of the development of the particular land 
use. Pre-urbanized areas are mostly agricultural, forestry or open space in nature. However, due to urbanization for keeping up with the demand to sustain human development in urban areas, these virgin lands would be later on converted to suit the needs of the human population. These land conversions virtually change the surface the land.

\subsection{Objectives of the Study}

The main objective of the study is to simulate the flooding caused by torrential southwest monsoonal rains at Valenzuela-ObandoMeycauyan (VOM) area, spanning a 24-hour interval within the month of August using the past land cover back in 2001 and the projected land cover in 2020 using FLO-2D and ArcGIS software.

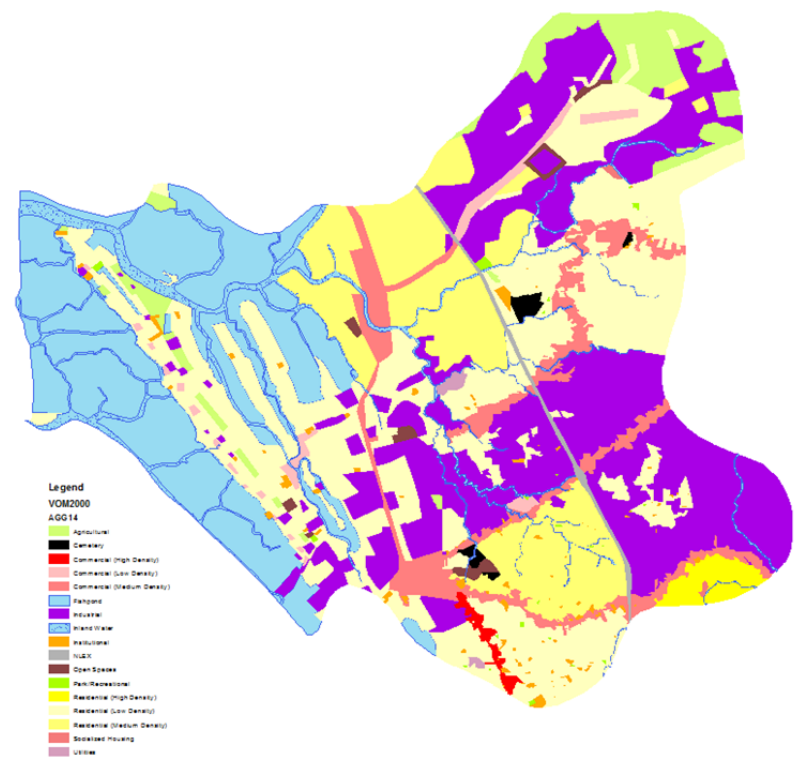

Figure 3. VOM 2000 Land Use

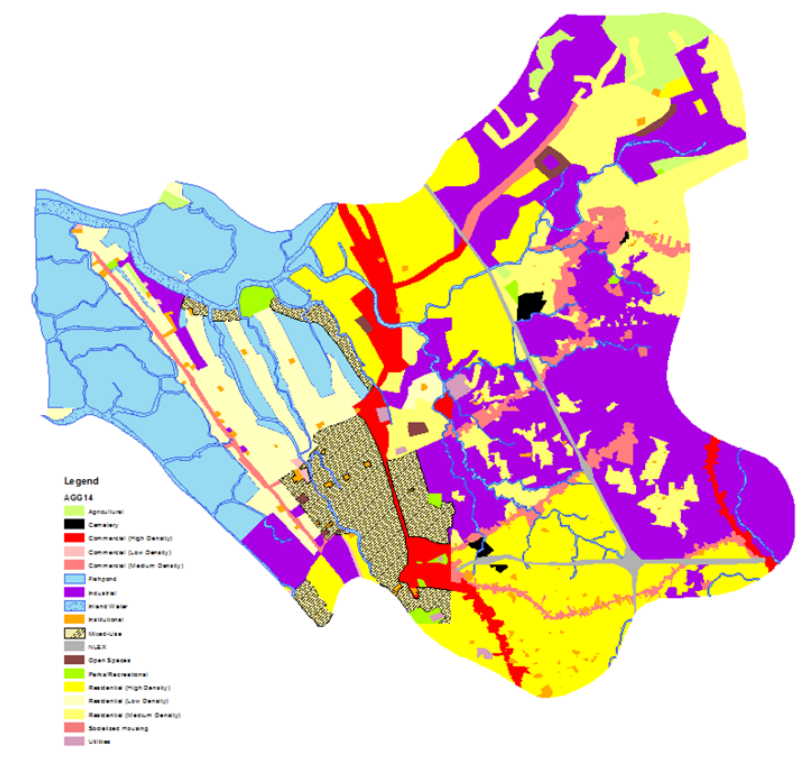

Figure 4. VOM 2020 Land Use

Specifically, it aims: to generate a flood hazard map caused by torrential southwest monsoonal rains using ArcGIS based from the hydrologic and hydraulic model created from Flo-2D; To assess the trend of flooding at VOM by comparing the scale of flooding between a 20-year difference in land cover using 2001 land cover and projected 2020 land cover; To identify where the depression storages occur during the Southwest Monsoonal rains using ArcGIS based from the simulations created from Flo-2D;

\section{MATERIALS AND METHODS}

The Past Yr 2000 and Projected Yr 2020 land use classification are derived from the previous study spearheaded by JICA mentioned earlier in this paper. The following corresponding values of the Manning's Coefficient per each land use classification were also taken from the same previous study.

Table 1. Manning's Value per Land Use Classification

\begin{tabular}{|c|c|c|}
\hline No. & $\begin{array}{c}\text { Area Classified by Land } \\
\text { Use }\end{array}$ & $\begin{array}{c}\text { Roughness } \\
\text { Coefficient }\end{array}$ \\
\hline 1 & Residential (Low Density) & 0.10 \\
\hline 2 & Residential (Middle Density) & 0.07 \\
\hline 3 & Residential (High Density) & 0.05 \\
\hline 4 & Commercial (Low Density) & 0.10 \\
\hline 5 & Commercial (Middle & 0.07 \\
\hline 6 & Density) & 0.05 \\
\hline 7 & Industrial & 0.10 \\
\hline 8 & Agricultural & 0.70 \\
\hline 9 & Parks/Recreational & 0.30 \\
\hline 10 & Open Spaces & 0.30 \\
\hline 11 & Utilities & 0.10 \\
\hline 12 & Fish Pond & 0.03 \\
\hline 13 & Cemetery & 0.30 \\
\hline 14 & Institutional & 0.10 \\
\hline 15 & Mixed Use & 0.07 \\
\hline \multicolumn{2}{|c|}{} \\
\hline
\end{tabular}

However, the boundaries of the study area was provided by the National Mapping and Resource Information Agency. The researchers used the Rainfall Duration Frequency data with 10year return period that was generated by PAGASA for selected stations near the study area. This specific RIDF return period was chosen being the Southwest Monsoon rainfall having a 10yr return period. Green-Ampt infiltration values has been maximized to simulate that run-off cannot further infiltrate the ground due to the built environment.

The FLO-2D PRO Software required a DTM file of the area that was investigated. We used DEM elevation derived from IFSAR data. The records for the area were the amount of rainfall which were required for simulation. The group has simulated the flood model of the topography of the covered area for both Yr. 2000 and Yr. 2020 and generated both a flow depth model and a flood map for monsoonal rain for each period.

\section{RESULTS AND DISCUSSION}

\subsection{Flow Depths}

The flow depths for the Valenzuela-Obando-Meycauayan Basin used were simulated through the use of FLO-2D Software. The figures shown here include the height in meters of flow depth. The Flow Depths are shown for the YR 2000 and YR 2020. Figure 5 and Figure 6 shows the flow depth obtained from the simulation of the Southwest Monsoon in accordance to the set of roughness values prescribed from the 2000 CLUP and 2020 CLUP respectively. 


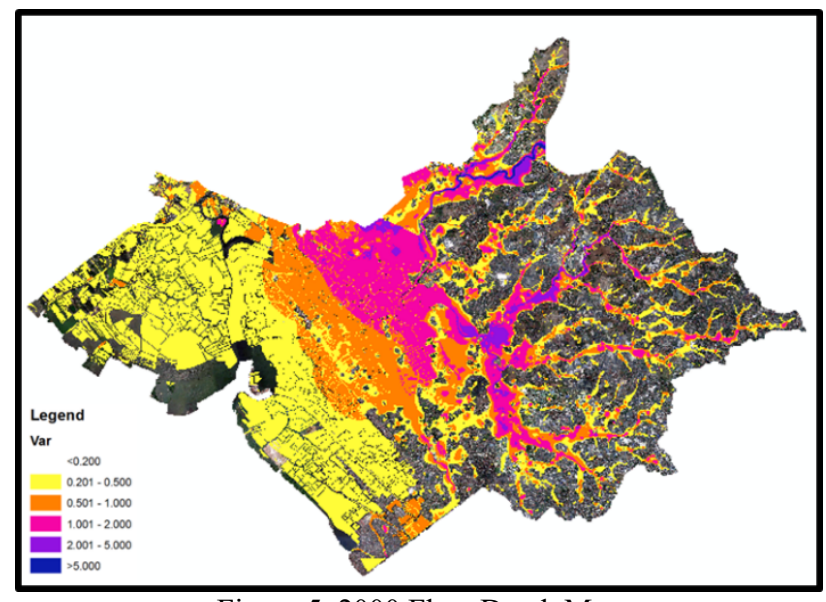

Figure 5. 2000 Flow Depth Map

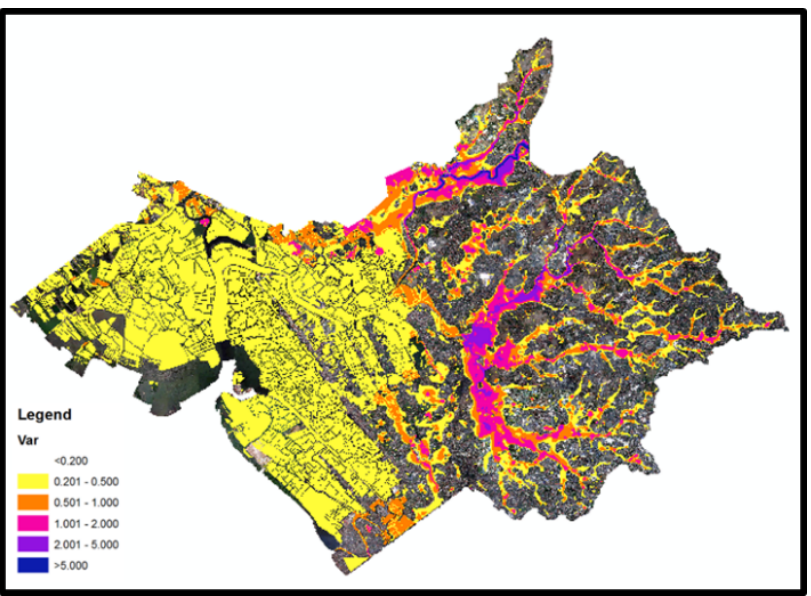

Figure 6. 2020 Flow Depth Map

Together, these two figures represent the flood height in VOM area for Year 2000 and Year 2020. According to these flow depth maps, there is a significant decrease in flood depth, especially in the low-lying regions where the fishponds are located. Flood depths from these particular areas have set from 5 meters to 0.2 meters. The area extent of flood depths ranging from 5 meters to 0.5 meters also decreased. Generally, flood depths in Obando and some parts of Meycauayan have lowered in respect to 20 -year difference in land use change. There is also a change in flood depth in some areas, however minimal.

\subsection{Hazard Maps}

The following figures show the Flood Hazard Maps generated from the Year 2000 and Year 2020. It is shown that there is a significant decrease in flood hazard in the vicinity of the fishponds

Figure 7 shows the Flood Hazard Map generated for the Year 2000. Figure 8 shows the Flood Hazard Map generated for the Year 2020. There is significant change in the severity of the flood hazard especially in the portion of the VOM where the majority of fishponds are located. In this particular area, flood hazard has decreased from Level 2 to Level 1 hazard. The extent of the Level 3 Hazard also decreased.

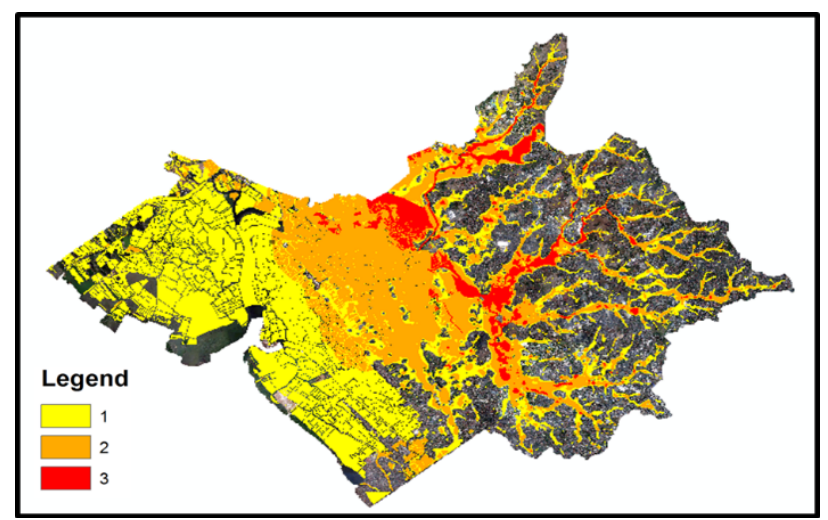

Figure 7. 2000 Hazard Map

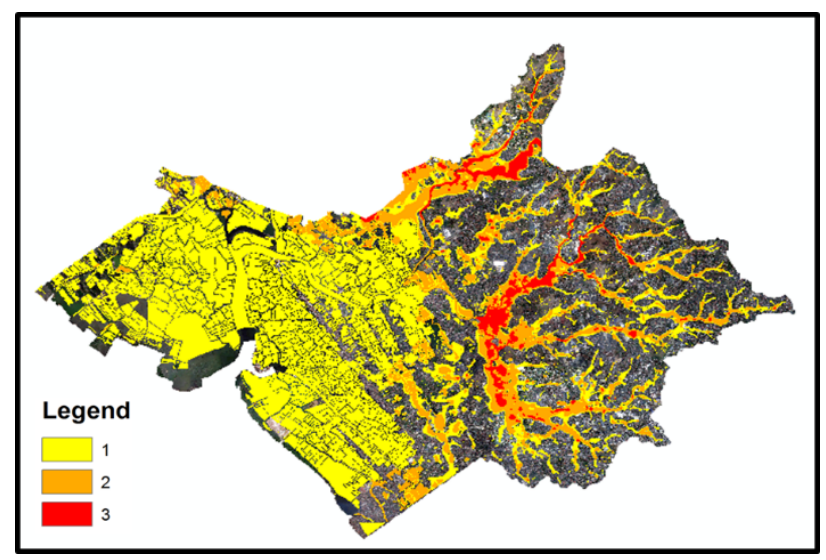

Figure 8. 2020 Hazard Map

\subsection{Areas of Interests}

The figures shown includes the change of manning's coefficient. Manning's coefficient change is inversely proportional to velocity of the flood waters; increasing the coefficient will give a low value of velocity which results to the hazard will be critical in the area and the water will take time to fully subsides. The hazard difference depends on the flood depth. Figure 9 shows the location of four particular areas the researchers have chosen to demonstrate as example how land use change influences flooding.

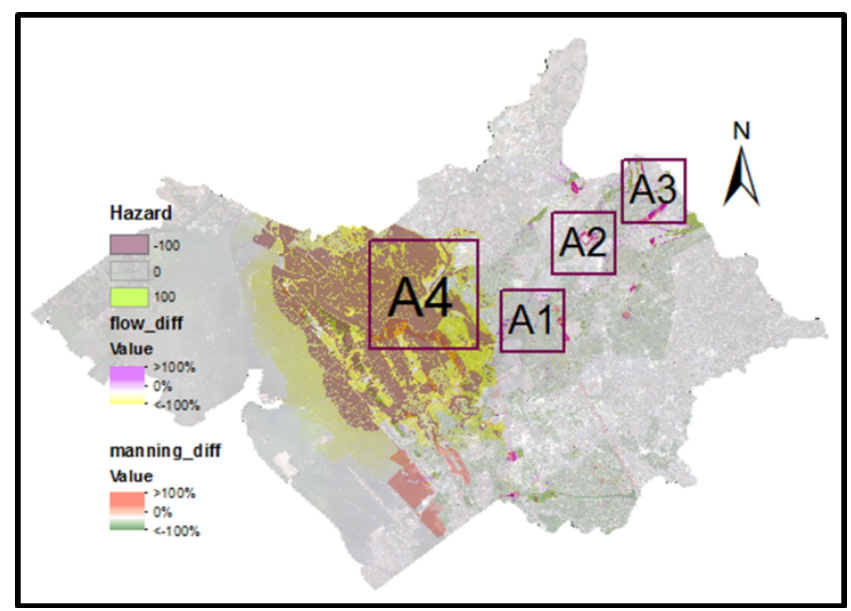

Figure 9. Locations of Areas of Interest 
3.3.1 Area 1: Figure 10 is located in the vicinity of Barangays Poblacion, Calvario, Zamora, St. Francis, Malhacan, Hulo and Langka, all located in Meycauayan. In terms of land use, the right side of NLEX is consists of residential areas while on the other side is a combination of open space, industrial and residential. In general, from 2000 to 2000 , the residential area upgraded from medium density to low density. This change in land use will result to smoothening of the area. In this figure, the increase of manning's coefficient denoted by pink along the riverbanks due to land use change resulted in a decrease of the velocity. The slowing down of flood waters combined with the area's flat topography caused the flood depth to rise in the vicinity as seen as patches of violet nearby. The rising flood depth then caused an increase of flood hazard hence the yellow green pixels in the area of the most increase in flow depth.

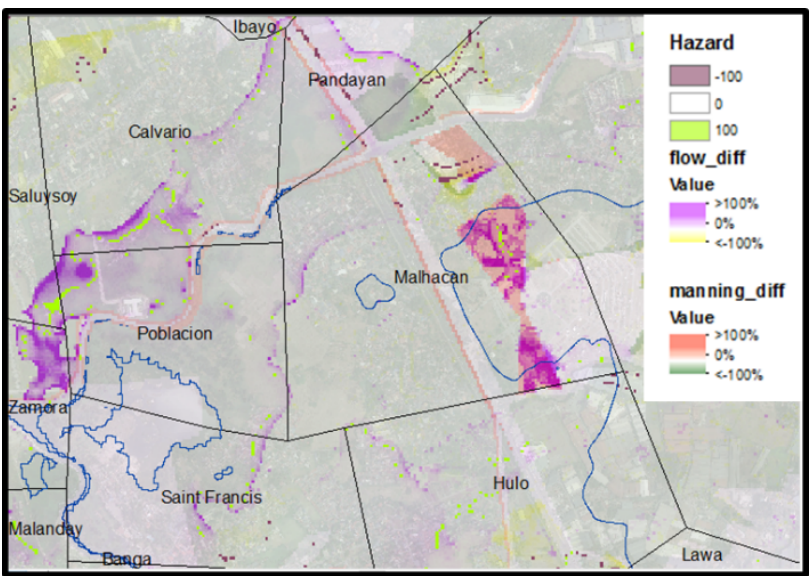

Figure 10. Change in Flooding due to Land Use change in Area

3.3.2 Area 2: The figure 11 meanwhile is located in the vicinity of the Barangays Lias, Lambakin and Iba. The area is primarily industrial with an open space serving as a buffer for an industrial park from the rest of the industrial lots. Topography of the area indicates a ridge near the industrial zones. The land use in the area also changed due to the de-zoning of the industrial park and widening of the open spaces buffer. In the areas that shifted from industrial to open space, the value of roughness coefficient went up from 0.07 to 0.30 . The outer industrial areas also encroached into the open space buffer, hence changing the outer segment of the open space to industrial use. This results to an opposite effect, with respect to the earlier instance. In the figure, the violet hollow square shaped-area indicated an increase in Manning value due to land use change. However, the green color surrounding it showed that the vicinity also experiences a decrease in roughness value over time. Areas where an increase of roughness are superimposed by violet covering thereby denoting an increase in flow depth. Meanwhile, in areas where decrease in roughness over time occurs, there's the presence of the color yellow, this time, indicating flow depth decrease. With the help of gravity, the flood waters are diverted and collected into the point of lowest elevation. With the inundation trapped in the depression, the flow depth inside rises as more water is added. The decrease in roughness, coupled with the steep slope, greatly increases the velocity of the flood thereby making the area to flood in a short amount of time which explains also the presence of flood hazard increase along the contours. The rising flood waters near the industrial complexes can cause lasting damages to the industrial facilities.

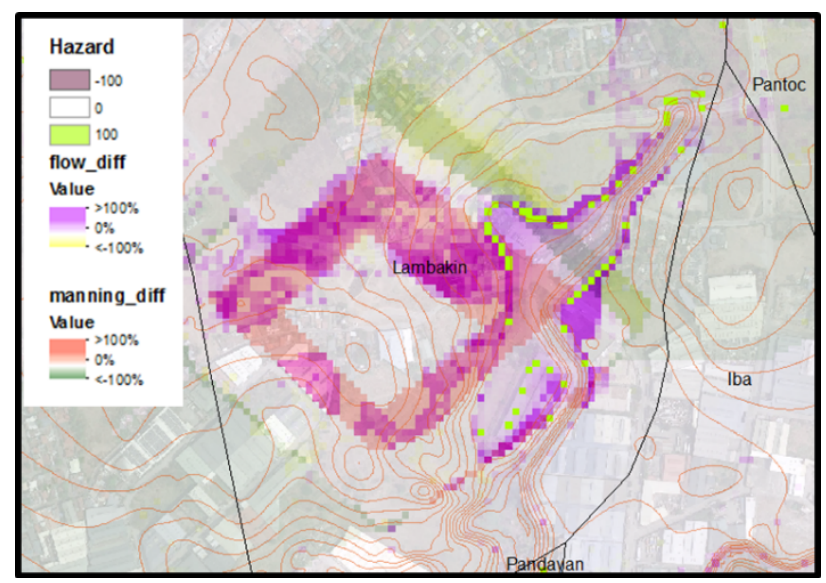

Figure 11. Change in Flooding due to Land Use change in Area 2

3.3.3 Area 3: Figure 12 is located in the far-flung region of VOM away from the urban areas. It is situated in the vicinity of Barangays Lambakin, Santa Rosa I, PrenzaII, Camalig, Pantoc and Perez. Among the barangays mentioned, only Camalig is densely populated while other barangays are mostly agricultural lands and open spaces. However, to accommodate the demand of housing the exploding urban population, the land use in the area changes. Some of the open spaces and agricultural lands are converted into low to medium density residential. The area's topography shows that it is slightly sloping downwards to the southwest with the southwest portion almost generally flat. The vicinity experiences both increase and decrease of Manning's value. While the decrease of roughness results to an acceleration in the flow of water, the flat topography lessens the distance the flood waters can travel in a span of time. This would explain the occurrences of rising flow depth over time in flat areas only after the water passes through areas where decrease in roughness happened. Meanwhile, in the area where there's a most increase in roughness does the flow depth increase is the greatest.

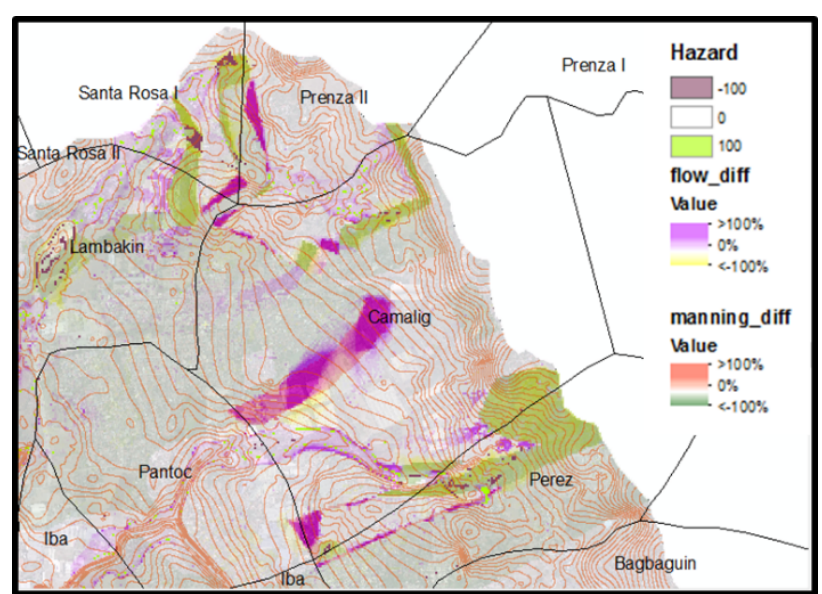

Figure 12. Change in Flooding due to Land Use change in Area 
3.3.4 Area 4: Figure 13 is situated in the fishpond district in Obando and Meycauayan. Urban development in the area is sparse at first. As rapid expansion of population gave rise to the need of residential space. Some of the fishponds in Paco, Longos and Coloong are converted to Mixed-Use of residential and commercial areas. Also, in nearby upstream areas like the Barangays Nagbalon, Poblacion II, Poblacion I, Saluysoy etc., medium-density residential land use is upgraded to high-density residential to accommodate housing demand caused by urban development. River inundation in the area is provided by the Meycauayan River. The figure shows that the hazard in the area decrease due to decrease in manning's coefficient in the right side of the figure. Flood water velocity in the area is high due to land use classification of the area. The area majorly uses a manning value of 0.03 due to fact that the area is mainly occupied by fishpond. The faster velocity over time in the vicinity results for the flood waters to drain away in a short period of time. The nature of the manning's coefficient, combined with the presence of decreasing manning's value due to land use change greatly affects the flood water to drain faster into Manila Bay.

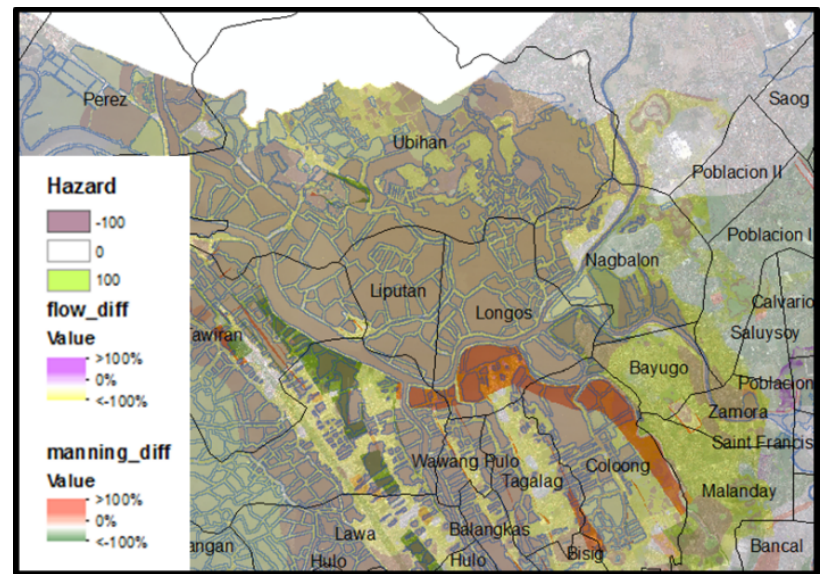

Figure 13. Change in Flooding due to Land Use change in Area 3

3.3.5 Depression Storages: By examining the hazard maps and flow depth maps generated by the simulations, the researchers have pinpoint the following areas of special interest regarding the depression storages. Figure 14 presents the location of the two depression storages the researchers have discussed. Figure 15 presents Depression Storage 1, located in Brgy. Poblacion, Ibayo and Saog. Figure 16 presents Depression Storage 2, located in Brgy. Poblacion, St. Francis, Hulo and Ibayo. The depression areas have an area of 232.2884 ha. and 193.0554 ha. respectively.

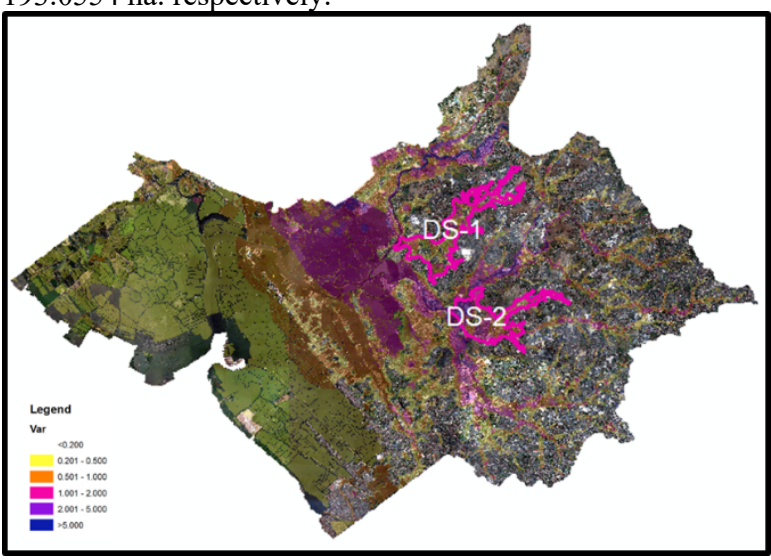

Figure 14. Locations of Depression Storages

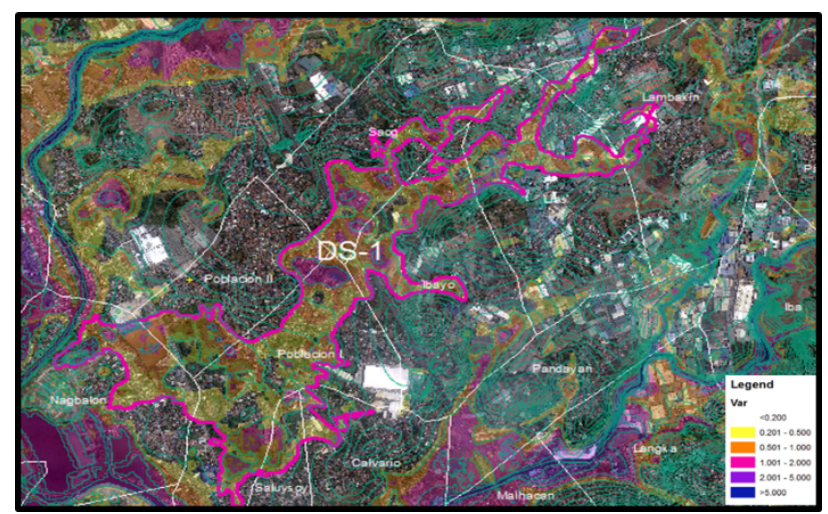

Figure 15. Depression Storage DS-1

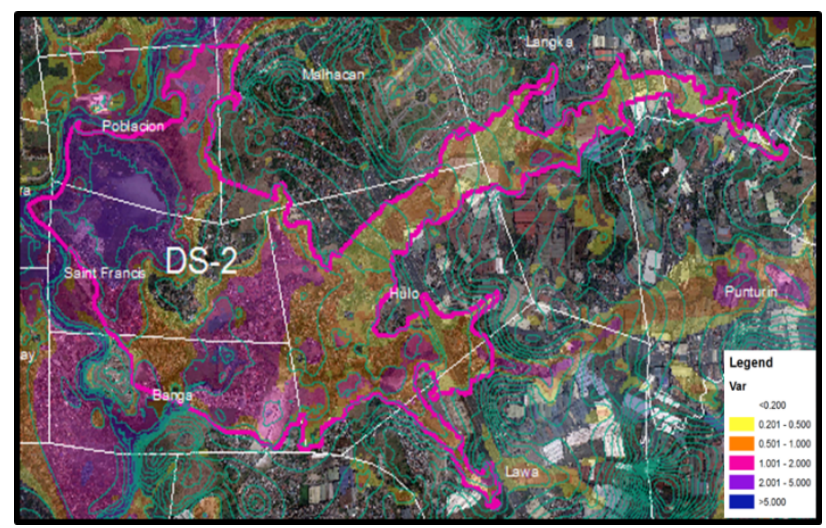

Figure 16. Depression Storage DS-2

3.3.6 Hydrographs: All locations of Hydrograph Stations within the basin are shown in Figure 17. Figures 18 and 19 shows the hydrograph results from the 2000-2020 flood simulations for the upstream and downstream respectively each with two hydrograph stations. All stations exhibit increases in discharge and steeper rising limb due to land use change over time. Computed lag time for 2000 and 2020 for each station also denotes that the arrival of the peak discharge becomes sooner over the years. Decreasing lag time is of concern due to the fact that most evacuation time allowance is dependent in lag time. The decreasing lag time would mean less time for the evacuation of the residents.

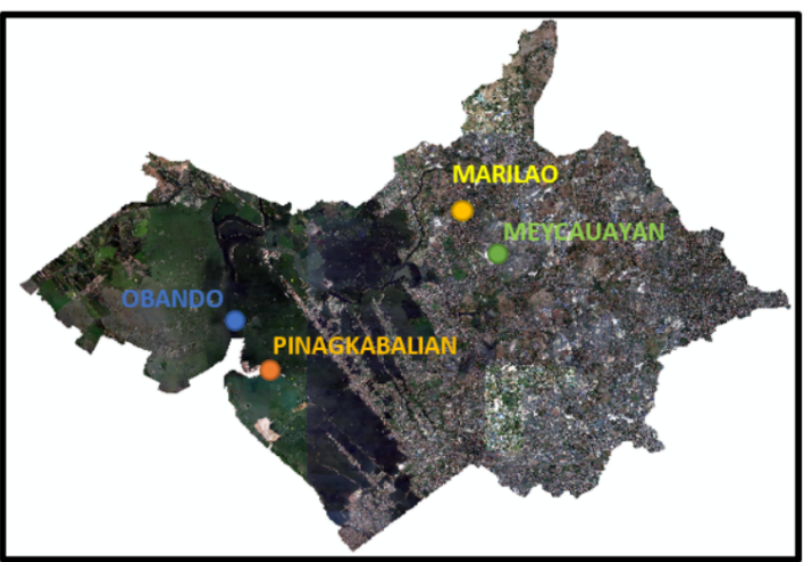

Figure 17. Locations of Hydrograph Stations 


\begin{tabular}{|c|c|c|c|c|c|c|c|c|c|c|}
\hline HYDROGRAPH & YEAR & $\begin{array}{l}\begin{array}{l}\text { amax } \\
\text { (cms) }\end{array}\end{array}$ & $\begin{array}{l}T @ \\
\text { Q } @ \text { max }\end{array}$ & $\begin{array}{c}\text { T@ } \\
P \max \end{array}$ & $\begin{array}{l}\text { Lag Time } \\
\text { (hrss) }\end{array}$ & \multicolumn{3}{|c|}{ Lag Time (h:m:s) } & Abs Diff & \% Diff \\
\hline \multirow{2}{*}{ MEYCAUAYAN } & 2000 & 9.44 & 16.3 & 11.83 & 4.47 & $4 \mathrm{~h}$ & $28 \mathrm{~m}$ & $12 \mathrm{~s}$ & \multirow{2}{*}{ in } & \multirow{2}{*}{$-6.71 \%$} \\
\hline & 2020 & 10.19 & 16 & 11.83 & 4.17 & $4 \mathrm{~h}$ & $10 \mathrm{~m}$ & $12 \mathrm{~s}$ & & \\
\hline \multirow{2}{*}{ MARILAO } & 2000 & 23.28 & 22.7 & 11.83 & 10.87 & $10 \mathrm{~h}$ & $52 \mathrm{~m}$ & $12 \mathrm{~s}$ & \multirow{2}{*}{$-6 \min$} & \multirow{2}{*}{$-0.92 \%$} \\
\hline & 2020 & 23.19 & 22.6 & 11.83 & 10.77 & $10 \mathrm{~h}$ & $46 \mathrm{~m}$ & $12 \mathrm{~s}$ & & \\
\hline \multirow{2}{*}{ PINAGKABALIAN } & 2000 & 0.13 & 35.5 & 11.83 & 23.67 & $23 \mathrm{~h}$ & $40 \mathrm{~m}$ & $12 \mathrm{~s}$ & \multirow{2}{*}{$-1410 \mathrm{~min}$} & \multirow{2}{*}{$-99.28 \%$} \\
\hline & 2020 & 0.04 & 12 & 11.83 & 0.17 & $\mathrm{Oh}$ & $10 \mathrm{~m}$ & $12 \mathrm{~s}$ & & \\
\hline \multirow{2}{*}{ OBANDO } & 2000 & 0.02 & 22.7 & 11.83 & 10.87 & $10 \mathrm{~h}$ & $52 \mathrm{~m}$ & $12 \mathrm{~s}$ & \multirow{2}{*}{$-6 \min$} & \multirow{2}{*}{$-0.92 \%$} \\
\hline & 2020 & 0.05 & 22.6 & 11.83 & 10.77 & $10 \mathrm{~h}$ & $46 \mathrm{~m}$ & $12 \mathrm{~s}$ & & \\
\hline
\end{tabular}

Table 2. Hydrograph Lag Time

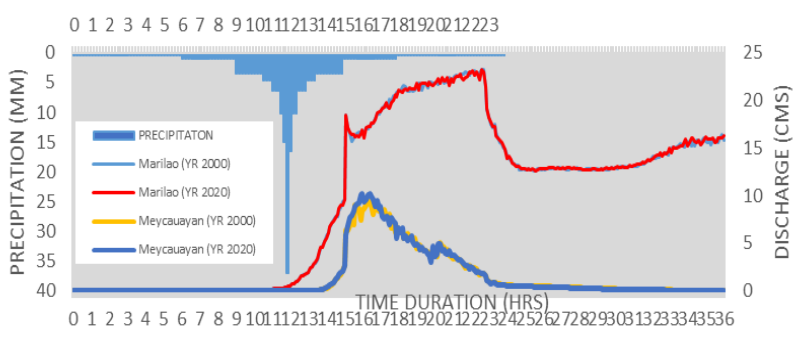

Figure 4.19 Upstream Hydrograph

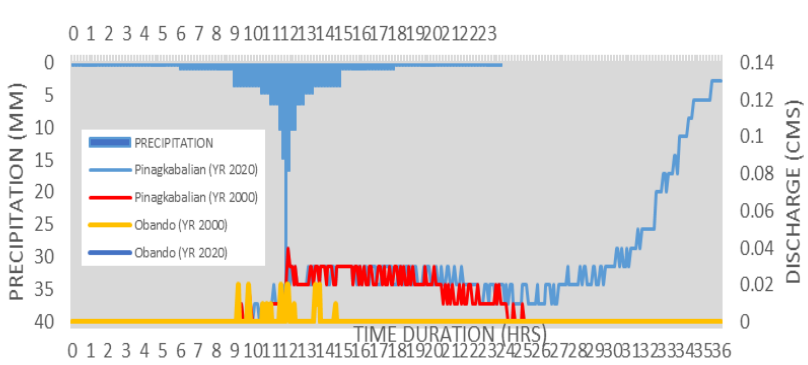

Figure 4.20 Downstream Hydrograph

\section{CONCLUSION}

The researchers were able to generate the 2000 and 2020 Flood Hazard Maps of the Valenzuela-Obando-Meycauayan. Considering the simulations of flooding using the past land use back in 2000 and the projected land use in 2020, minimal decrease in flooding was noticed. In most portions of the study area, the impact of land use change on flood formation in the VOM area did not appear to be alarming due to a low degree of land use change. Also, even there were areas which land use has changed, their equivalent manning's coefficient remained the same, which explains the lower resistance to flood flows in flood plains. The researchers were also able to identify two depression storages in the area based from the simulations.

\section{RECOMMENDATIONS}

The following proposals for future research projects are suggested:

1.Increasing the difference of time period of the Land Use Change

2.Increasing the variety and the precision of Manning's Coefficient Values per Land Use to be used

3.Simulating flood models of different rainfall intensity return period

4.Implementation of a combined 1D-2D Flood Model

\section{ACKNOWLEDGEMENTS}

We would like to extend our gratitude to our adviser, Engr. John Manuel Vergel and our thesis coordinator Dr. Armi CunananYabut for their guidance, advises and their knowledge and support all throughout the research. They gave us motivation and encouragement that we need to accomplish this research and writing. Without them, this research paper would not be possible.

Our sincere thanks to the persons who help us in our data gathering Engr. Mel Vergino of Valenzuela Flood Control for Valenzuela Land use plan and the suggestion of the project area to consider, Engr. Bayani Torres Jr. of Meycauayan City Planning and Development Office for Meycauayan Comprehensive Land Use Plan, Ms. Monique Ocfemia of Namria for the Digital Terrain Model, Engr. Resito David of DPWH for referring us to Engr. Kaku, Engr. Shinju Kaku of CTI Philippines for the feasibility study that serves as a basis of our thesis, and Dr. Alfredo Mahar Lagmay and Mr. Neil Tingin for teaching us to do the modelling and lending us computers for us to be able to simulate our watersheds.

\section{REFERENCES}

Badilla, R. A., 2008: Flood Modelling in Pasig-Marikina River Basin.

Bedient, P., \& Huber, W., 1988: Hydrology and Floodplain Analysis.

Chow, V. T., 1988: Applied Hydrology. McGraw-Hill Book Company.

CTI Engineering, 2001: Feasibility Study on ValenzuelaObando-Meycauayan (VOM) Area Drainage System Improvement Project.

Flood Forecasting and Early Warning, 2013: Associated Programme on Flood Management.

Green, W. H., \& Ampt, G., 1911: Studies of Soil Physics. Part 1 - The Flow of Air and Water through Soils. J. Agric. Sci., pp. 4:124.

Haan, C., Johnson, H., \& Brakensiek, D. L., 1982: Hydrologic Modelling of Small Watersheds.

Maidment, D. R., 1993: Handbook of Hydrology. New York: McGraw-Hill.

1991: Manual and Guidelines for Comprehensive Flood Loss Prevention and Management. United Nations Economic and Social Commission for Asia and Pacific.

2003: Manual on Flood Control Planning.

Rientjes, T. H., 2007: Modelling in Hydrology. International Institute for Geo-Information Science and Earth Observation.

Ruji, E. M., 2007: Hydrodynamic Modelling for Flood Hazard Assessment.

Santillan, J., Paringit, E., \& Makinano, M., 2011: Integrated Landsat Image Analysis and Hydrologic Modeling to Detect Impacts of 25-Year Land-Cover Change on Surface Runoff in a Philippine Watershed. Remote Sensing. 
Smith, L., 1997: SATELLITE REMOTE SENSING OF RIVER

INUNDATION AREA.

USGS.com, 2007: (United States Geological Survey) Retrieved

from http://www.usgs.gov/science/science.php?term=398 